\title{
Analysis of The Effect of Covid-19 Towards L2 English Speaking Performance
}

\author{
Rahmi Djafar \\ ${ }^{1}$ Prodi Ilmu Komputer/ Informatika, Universitas Megarezky Makassar \\ rahmi.djafar223@gmail.com
}

\begin{abstract}
Speaking is one of important factors in communicating. Like English Speaking as a international language and student and lecturer must know how to apply it. Students need to practice after found the treatment from lecturer, face to face. But, teaching Speaking in current situation of Pandemic Covid-19, face some obstacle on it. The pandemic made as have to social distancing and online learning. This research aims to analysis the effect of Covid-19 toward L2 speaking performance which can improve speaking ability on this pandemic, even in difficult situations like learning by virtual. This research method is descriptive research. Conducted by using google form or online. The findings result of this research, was English speaking class in Pandemic Covid-19, more difficult, then normal era. Students or teacher cannot here clearly, about discussion. It was depending on signal as a technology product. Besides, students lack of vocabularies and did not know of pronounce some vocabularies.
\end{abstract}

Key Word: : Covid-19, Speaking, performance

\section{INTRODUCTION}

English is International language that has been using as international communication. Especially in college level, student have to know it.

Every languages, speaking is important as a communication each other. In learning English, speaking skill is requires development alongside, even in pandemic Covid-19 e-learning system.

Accordingly, one conclusion from the research are, these results is that agency in language choice can influence the path of development in the L2: Students' L1 remains an important and useful means of communication, and investment in L2 development is impeded by the subjective assessment of communicative needs in the multilingual space (Baumgarten, 2016). Communication means good speaking each other.

Suggestions for speaking improvement for EFL learners mainly covered listening skills, which included listening to music, watching movies, and frequent practice of listening and speaking skills from multimedia websites. The taskbased learning design in this qualitative action research could be applied to promote a particular skill or integrated-skill pedagogy in EFL/ ESL and other language learning contexts (Boonkit, 2010). It shows that, student could hear clearly or understand, based on how they listen and spell of each word and sentences. Hence, they know vocabularies.

Therefore, the development of a reliable model on English speaking skill assessment is very important and it will hopefully bring about English language teaching improvement (Srikaew et al., 2015).

In learning English, student have to practice in front of the leader to know the problem or incorrect English especially speaking. But, the important is, they can do by they self, because in class, teacher and students limited by the time.

But, pandemic Covid-19 isolated people in facing each other. How the Covid19 limit us and activity.

The pandemic Covid-19 emerged in Wuhan, China, on last 2019 until today. It can be avoided and the disease is spread massive around the world and it has influence, and generated substantial impact on daily activity. Although in Indonesia, the first case emerged on January 2020.

All country in the world implemented physical distancing, as one the way in cutting the transmission each to each.

In this study we estimate the early transmission potential of SARS-CoV-2 in 
Lima, Peru. Our current findings point to sustained transmission of SARS-CoV-2 in the early phase of the outbreak, with our estimate of the mean reproduction number $\sim 2.3$. The COVID-19 epidemic in Lima followed an early exponential growth trend, which slowed down and turned into an almost linear growth trend ( $\mathrm{p} 0.5$ ), which appears to be tied to broad scale social distancing interventions put in place by the government (Munayco et al., 2020).

On this journal, shows data that social distancing or physical distancing could decrease the Pandemic transmission. Therefore, in education system, physical distancing also applied. Especially in university, that has many students and lecturer that have to emerged this protocol of Covid-19 too.

The situation in Indonesia, approximately seven months, during this pandemic, activity out there nearly stop or limit, like in school or university. It has impact in educational management system study. By arrange e-learning system, teacher dan student could make interaction, while physical distancing applied.

The development of information technology makes all things pushed more innovatively by making technology development discouraging. All sectors, not least the learning model which also has to follow more advanced ways based on the internet.

Learning model will certainly go to technological stages such as cyber and virtual learning, moreover during the current situation as Covid-19. The learning model that begins is done in a way like direct faceto-face, suddenly changed with online-based learning.

On some journal, e-learning already applied said "Our study did not take into consideration the beliefs of learners about elearning. Discussions with learners combined with observations might present a further occasion to gain insight into learner-centred practices in contexts of e-learning" (Murphy \& Rodríguez-Manzanares, 2008).
This learning model makes many become ineffective, one of which is in learning English speaking. Learning to speak requires some models learning like the personal approach between lecturer and student, it also needs a longer and more effective time.

Speaking using a performance instrument during this pandemic, like video conferences, or voice note, as a way to solve physical distancing.

This is compounded by the availability of uneven quality of network in all places and areas of lecturers or students. Thus, the impact on sound and images are disturbed or not optimal when communication is running between one student and another student or between students and lecturers. But, we facing the problem in learning speaking.

The important instrument in learning speaking depend on the sound that network stable, it could be misunderstanding between the object and the subject of conversation.

A bad network can also cause lecturer instructions to students not to be conveyed properly. Although the lecturer has tried to give the best when presenting the material in learning of English speaking via online, but due to a bad network, the message or instructions of the lecturer are not conveyed completely. As a result, the level of student understanding of the material presented will not be maximal and vice versa.

From the experiment proposed here, we got a significant information suggesting that English sentence memorize has an effect on the enhancement of the speaking skill, which may give a user of the proposed elearning the educational hint/motivation. When the feature of an English e-learning is designed, it ought to be considered that memorization as an educational methodology is efficient in order to enhance the speaking skill (Kitagaki, 2013)

The development of information technology makes all things pushed more innovatively by making technology development discouraging. All sectors, not least the learning model which also has to 
follow more advanced ways based on the internet.

Ready or not ready, learning model will certainly go to technological stages such as cyber and virtual learning, moreover during the current situation like this such as the spread of Coronavirus. The learning model that begins is done in a way like direct face-to-face, suddenly change with onlinebased learning.

This learning model is done now days suddenly makes many become ineffective, one of which is in learning English speaking. Learning to speak requires some models learning like the personal approach between lecturer and student, it also needs a longer and more effective time.

English speaking is not an easy task because speakers should know many significant components like pronunciation, grammar, vocabulary, fluency, and comprehension. (Leong \& Ahmadi, 2017)

1. Pronouncing

Pronunciation is the act of giving the true sounds of letters in words, and the true accents and quantity of syllables. Pronunciation refers to the ability to use the correct stress, rhythm, and intonation of a word in a spoken language. Besides, pronunciation is the act or result of producing the sounds of speech, such as: articulation stress and intonation, often with reference to some standard of correctness or acceptability (Mulatsih, 2018).

It shows that, ff speakers does have not a good pronunciation, automatically the respondent not understand what the message or communication does running well.

If students want to be able speak fluently in English, they need to be pronounce phonemes correctly, use appropriate stress and intonation patterns and speak in connected speech (Harmer. J, 2008). Formerly, to pronounce every single words, students mast be practice how to spell the word. It could be from song or many treatment by learn in class room or can be found in YouTube.
Every languages, need to practice to accustom in communication, so that, every students or someone in need learning English, must be practice for more, after get the lesson.

2. Grammar

Grammar is one of part to arrange each word to sentences. For example, tenses as common use in communication. In formal communication, speakers and respondence need to use grammar, to make sure a specific message.

3. Vocabulary

Vocabulary learning is one of the most important factors that foreign language learners encounter during the process of learning a foreign language. Vocabulary learning used to be a neglected aspect of language learning. In recent years, however, interest in this area has grown enormously. Language teachers have been keen in searching for effective approaches to enhance vocabulary learning. Vocabulary learning is more important than familiarity with the form and meaning of a word. (Ahmadi et al., 2012).

4. Fluency

Good pronunciation does not just mean saying individual words or even individual sounds correctly (Harmer. J, 2008). In communicating, fluency must be clear, to avoid misunderstand.

This research aims to know, about the element of speaking above, which part that difficult by students in learning speaking, in pandemic Covid-19, and to know what the problem of speaking comprehension when the class arrange as virtual.

\section{METHOD}

This research as a qualitative research or library research. As a library research, hence the research data source as a literature and descriptive from the researcher found. The data collected by literature searching, and used the instrument is questionnaire in google form, and face in zoom meeting cloud. There are seven yes or no question, and there are four question, need to answered by their 
opinion. The population were approximately 2.000 students of Universitas Megarezky Makassar and samples were 34 students. The research was conducted from October 2020.

\section{FINDING AND DISCUSSION}

This parts contains the students English speaking performance in pandemic Covid-19, by the instrument of questionnaire and virtual class by Zoom meeting cloud, while in questionnaire reveal, many students found obstacle in English speaking performance.

Based on questionnaire on "yes" and "no" question, records by the element of speaking, and found the value bellows:

1. Students speaking pronunciations

There are $61,3 \%$ students said difficult and $38,7 \%$ students said easy. It means, pronunciation need to improve for better speaking.

\section{Grammar}

There are $54,8 \%$ students said difficult and $45,2 \%$ easy. On Grammar, the percentage quite different. But, the students have to prepare a good grammar, in speaking, to avoid misunderstanding.

3. Vocabulary

From the questionnaire there are $38,7 \%$ difficult $61,3 \%$ easy. On Vocabulary section, many students said easy in memorizing, but if the researcher compare with how to pronounce it, students still confuse ant need to improve it.

4. Fluency

$80,6 \%$ difficult and $19,4 \%$ easy. On speaking fluency, it too difficult by most of students.

In hence, on interview section, most of students answer that, learning speaking in pandemic Covid-19, more difficult. Many reason about that, is because the element of speaking cannot hear clearly and the percentage are $67 \%$ and $32,3 \%$ said easy to learn English Speaking by using zoom, video call, or whatsApp sometimes face internet problem. Whereas, communicate need clearly voice.

About Speaking performance in pandemic Covid-19 era, they many of them said more difficult, because of signal if speaking by video or by phone.

Problem English speaking by phone or video, students difficult to hear lecturer command clearly. Prefer to face to face.

This is compounded by the availability of uneven quality of network in all places and areas of lecturers or students. Thus, the impact on sound and images are disturbed or not optimal when communication is running between one student and another or between students and lecturer.

Though sound is an important instrument in learning speaking because it supports and clarifies the phonology department. We must know when the sound that is problematic due to network interference can cause misunderstanding between the object and the subject of conversation.

\section{CONCLUSION}

Based on the researcher finding, the problem of speaking in pandemic Covid-19, is signal or phone data. But we know that, pandemic Covid-19. If The signal error, automatically, the communication is failure, or may take long time in distributing one by one. But, in digital era this day, we need it.

\section{SUGGESTION}

The researcher can also suggest, that speaking performance, there are some technique that can apply by students. In virtual class, it must be limited by the time, but if students learning by their self, it can improve speaking performance. Some techniques are, practice alone or partner, using learning English on youtube, and try to accustom to listening and write it.

\section{REFERENCES}

Ahmadi, M. R., Ismail, H. N., \& Abdullah, M. K. K. (2012). Improving Vocabulary Learning in Foreign Language Learning Through Reciprocal Teaching Strategy. International Journal of Learning and Development.

https://doi.org/10.5296/ijld.v2i6.2882

Baumgarten, N. (2016). L2 English 
Academic Speaking Development: Insights from a Multilingual University Context. Procedia - Social and Behavioral Sciences, 232(April), 145153.

https://doi.org/10.1016/j.sbspro.2016.10 .039

Boonkit, K. (2010). Enhancing the development of speaking skills for nonnative speakers of English. Procedia Social and Behavioral Sciences, 2(2), 1305-1309.

https://doi.org/10.1016/j.sbspro.2010.03 .191

Harmer, J. (2008). The practice of English language teaching (4rd ed). London: Longman

Kitagaki, I. (2013). Effect of English Short Sentences Memorization on the Speaking Skill and the E-learning of English. Procedia - Social and Behavioral Sciences, 103, 348-351. https://doi.org/10.1016/j.sbspro.2013.10 .343

Leong, L.-M., \& Ahmadi, S. M. (2017). An Analysis of Factors Influencing Learners' English Speaking Skill. International Journal of Research in English Education. https://doi.org/10.18869/acadpub.ijree.2 .1 .34

Mulatsih, D. (2018). Pronunciation Ability by Using English Song in Indonesian Student of Unswagati Cirebon. Academic Journal Perspective: Education, Language, and Literature. https://doi.org/10.33603/perspective.v2i 2.1665

Munayco, V., Tariq, A., Rothenberg, R., Soto-, G. G., Reyes, M. F., Valle, A., Rojas-mezarina, L., Loayza, M., \& Chowell, G. (2020). Early transmission dynamics of COVID-19 in a southern hemisphere setting: Lima-Peru: February 29 the March 30 th, 2020. 5, 338-345.

https://doi.org/10.1016/j.idm.2020.05.0 01

Murphy, E., \& Rodríguez-Manzanares, M. A.
(2008). High School Teachers' Beliefs about Learner-Centred E-Learning. ELearning and Digital Media, 5(4), 384 395.

https://doi.org/10.2304/elea.2008.5.4.38 4

Srikaew, D., Tangdhanakanond, K., \& Kanjanawasee, S. (2015). Development of an English Speaking Skill Assessment Model for Grade 6 Students by Using Portfolio. Procedia - Social and Behavioral Sciences, 191, 764-768. https://doi.org/10.1016/j.sbspro.2015.04 .715 